\title{
Glycosylation Regulates CD38 Assembly on the Cell Surface 糖鎖付加は細胞膜上でのCD38のアセンブリを制御する
}

\author{
Hara-Yokoyama, Miki \\ Section of Biochemistry, Department of Hard Tissue Engineering, Graduate School of Medical and Dental Sciences, \\ Tokyo Medical and Dental University 1-5-45 Yushima, Bunkyo-ku, Tokyo 113-8549, Japan \\ FAX: 81-3-5803-0187, E-mail: m.yokoyama.bch@tmd.ac.jp \\ (Received on July 25, 2013, accepted on August 29, 2013)
}

Key Words: CD38, glycosylation, assembly, ecto-enzyme, lipid rafts

\begin{abstract}
The leukocyte cell-surface antigen CD38 is a Type II transmembrane glycoprotein. $\mathrm{CD} 38$ is the major $\mathrm{NAD}^{+}$glycohydrolase in mammals, and it also acts as a raft-dependent signaling molecule to promote cell proliferation or death. Recently, we identified the structural basis for CD38 tetramerization on the cell surface, which underlies the catalytic activity and the localization of CD38 in lipid rafts. The N-linked glycosylation sites are located in strategic positions to prevent further self-association of the tetramer. The glycosylation is likely to ensure the function of $\mathrm{CD} 38$, by regulating the cell-surface assembly.
\end{abstract}

\section{A. CD38 Is a Versatile Protein Acting as an Ecto- Enzyme and a Signaling Molecule}

CD38 is an ecto-enzyme, as its catalytic activity is mediated by its extracellular domain (1). CD38 is the major NAD ${ }^{+}$glycohydrolase in mammals (2). CD38 cleaves the N-glycoside linkage of $\mathrm{NAD}^{+}$or $\mathrm{NADP}^{+}$to generate ADP-ribose/cyclic ADP-ribose or $\mathrm{NAADP}^{+}$, which triggers intracellular calcium mobilization in an $\mathrm{IP}_{3}$-independent manner (Fig. 1) (3). The catalytic activity of CD38 is required in various processes, such as insulin $(4,5)$ and oxytocin (6) secretion, neutrophil chemotaxis (7), and dendritic cell trafficking (8). The mechanism that enables the product of $\mathrm{CD} 38$ to function intracellularly, while the catalytic activity is associated with the extracellular domain, has not been fully clarified (this point will be discussed below in more detail). On the other hand, CD38 associates with various supramolecular complexes within lipid rafts in T cells (CD38/CD3/Lck/LAT) (9), B cells (CD38/ BCR/CD19/CD81) (10, 11), natural killer cells (CD38/CD16) (12), monocytes (CD38/MHC Class II/CD9) (13) and mature dendritic cells (CD38/CD83/CD11b/CD81) (14). The association of CD38 with lipid rafts is involved in the initiation of CD38-mediated signaling to trigger cell activation and proliferation (3). From a clinical point of view, CD38 is recognized as a negative prognostic indicator in B-cell chronic lymphocytic leukemia patients and in individuals infected with HIV (3). Recently, CD38 has been con-
要 約

リンパ球表面抗原 CD38 は、1 回膜貫通型の糖タンパク

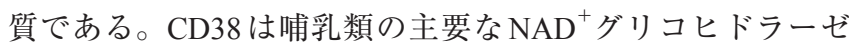
であり、脂質ラフトに局在して細胞増殖・細胞死を誘導する シグナル分子としても機能する。筆者らは、細胞膜上におけ るCD38の四量体形成の構造基盤を明らかにした。四量体構 造の形成は、 $\mathrm{CD} 38$ の触媒活性部位の維持と脂質ラフトへの 局在化に重要である。また $\mathrm{N}$ 型糖鎖は、CD38の四量体構造 がさらに会合することを抑制する位置に存在する。糖鎖は膜 上でのアセンブリを介して CD38の機能を制御することが示 唆された。

A. CD38はエクト型酵素であり、シグナル分子としても はたらく多芸なタンパク質である

CD38 は細胞外ドメインに触媒活性をもつエクト型酵素

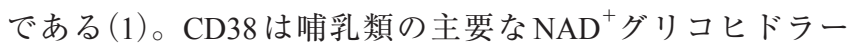
ゼであり (2)、 $\mathrm{NAD}^{+}$やNADP ${ }^{+}$のグリコシド結合を切断する (図1)。これに伴って産生されるサイクリックADPリボー ス、ADPリボース、ニコチン酸アデニンジヌクレオチド $\left(\mathrm{NAADP}^{+}\right)$は、イノシトール三リン酸とは異なる細胞内力 ルシウムストアからカルシウムを動員する(3)。CD38ノック アウトマウスでは、インスリン $(4,5)$ やオキシトシン (6) の 分泌や、好中球や樹状細胞の遊走が低下する $(7,8)$ など多様 な表現型が報告されている。これらの現象は、主にカルシウ 厶動員の欠落に起因する。触媒活性が細胞外ドメインに存在 するのにもかかわらず、その産物が細胞内で機能するしくみ は十分には解明されていない（後述）。一方、CD38 は細胞膜 上の脂質ラフトにおいて、さまざまな免疫受容体と結合して いる。 $\mathrm{T}$ 細胞 (CD38/CD3/Lck/LAT) (9)、B 細胞 (CD38/BCR/

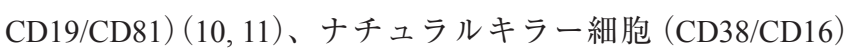
(12)、単球 (CD38/MHC Class II/CD9) (13)、樹状細胞 (CD38/ $\mathrm{CD} 83 / \mathrm{CD} 11 \mathrm{~b} / \mathrm{CD} 81)(14)$ の例が報告されている。抗 CD38 抗体の刺激により細胞増殖や細胞死のシグナルが立進する (3)。臨床面では、CD38 は白血病や HIVの重篤度のマーカー 


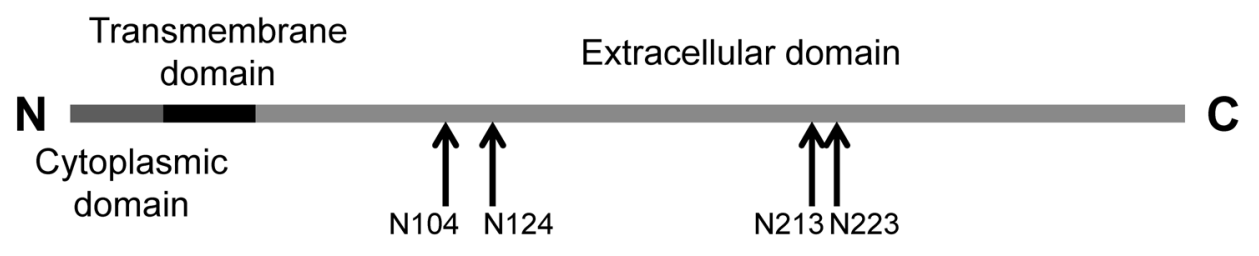

$\mathrm{N}$-linked glycosylation sites
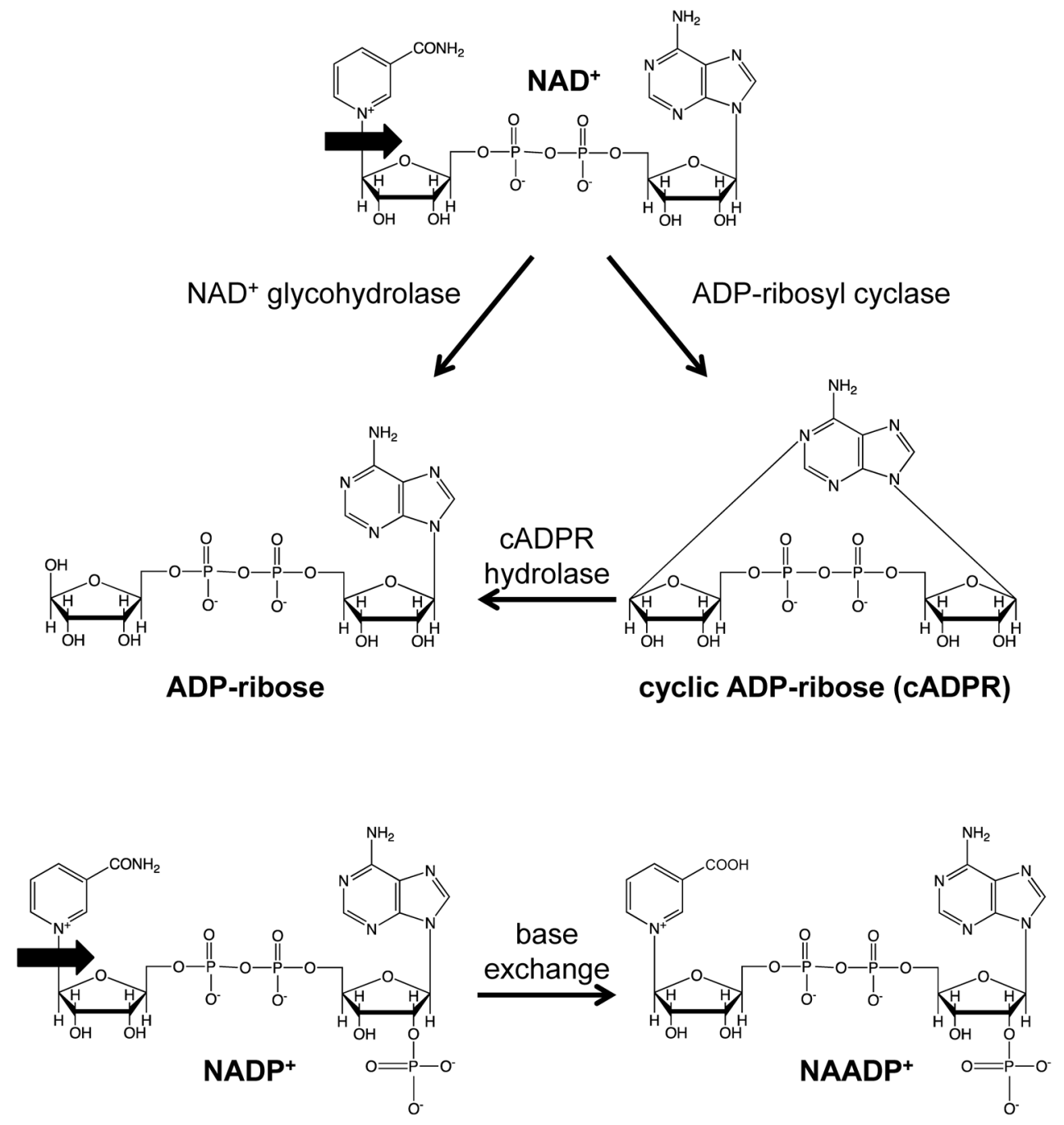

Fig. 1. The primary structure and the enzymatic activities of CD38.

sidered as a potential therapeutic antibody target for the treatment of multiple myeloma (MM) (15). Daratumumab, a novel mAb against human CD38, is currently in a phase I/II safety and dose determination study for the treatment of MM.

B. The Assembly of CD38 Is Distinct from Those of the Other Family Members, Although Their Protomer Structures Are Well Conserved

The origin of the ADP-ribosyl cyclase dates back to about 555
になることが知られていた $(3)$ 。近年では多発性骨髄腫に対 する抗体創薬の有望な標的としても注目されており、Daratumumab（抗ヒトCD38モノクローナル抗体）は第 I/II相臨床 試験が進められている $(15)$ 。

B. CD38の三次構造は進化的に保存されているが、アセ ンブリについてはCD38独自の様式をもつ

ADP リホシルシクラーゼの出現は 5 億 5500 万年前に さかのぼり (16)、その後アメフラシの ADP-ribosyl cyclase, 


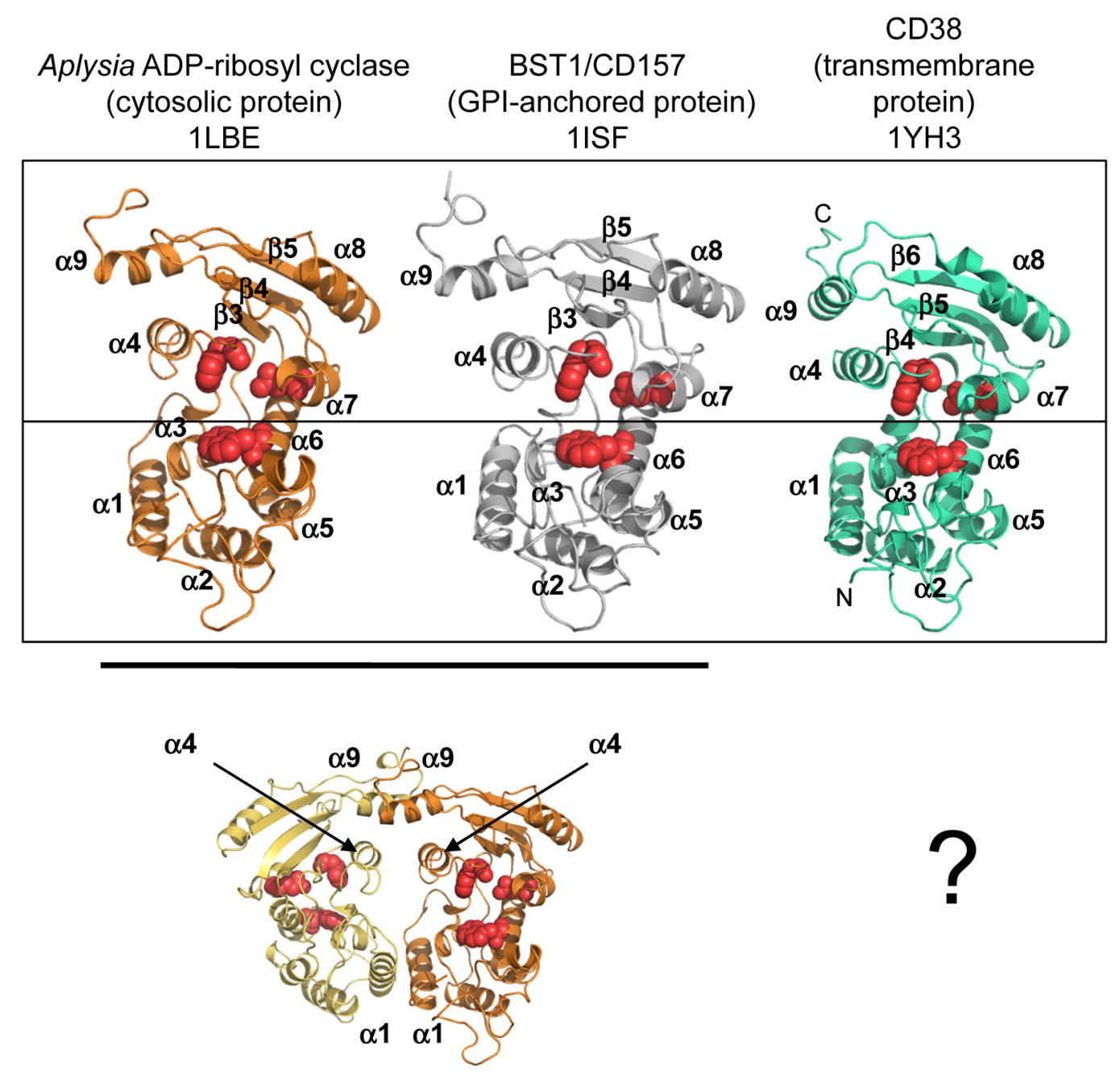

Fig. 2. The tertiary structures of the ADP-ribosyl cyclase family proteins and the dimer structure of Aplysia ADP-ribosyl cyclase. The catalytically important residues are colored red.

million years ago (16). The Aplysia ADP-ribosyl cyclase, CD157/ BST-1, and CD38 are believed to derive from a common ancestor. Although the entire primary structures are not well conserved among the family proteins, the overall topology of the extracellular domain of CD38 is similar to those of the other proteins (Fig. 2) (17-19). However, the three proteins differ from each other in terms of their membrane association. Aplysia ADP-ribosyl cyclase is cytosolic, while BST-1 and CD38 are membrane-bound via a glycosylphosphatidylinositol (GPI)-anchor and a transmembrane domain, respectively.

Biochemical and crystallographic analyses revealed that Aplysia ADP-ribosyl cyclase and a soluble form of BST-1 exist as dimers $(20,21)$. The interface of the dimers showed the stable homophilic interaction existing within the crystal packing, in both cases (Fig. 2). On the other hand, although twenty-nine structures of human CD38 have been deposited, a similar homophilic interface was not observed. The orientation of the C-terminal $\alpha$-helix
CD157/BST-1, CD38に受け継がれてきた。これらのタンパク 質は、一次構造全体の相同性は低いが、ほぼ同一の三次構造 を示すファミリーである（図2）(17-19)。しかしアメフラシ のADPリボシルシクラーゼは可溶性タンパク質であるのに 対して、CD157/BST-1, CD38はそれぞれGPIアンカー型膜夕 ンパク質、膜貫通タンパク質であり、膜との関係は異なって いる。

生化学的解析および結晶解析の結果から、アメフラシの ADP リボシルシクラーゼと CD157/BST-1 は二量体として存 在する $(20,21)$ 。結晶中でのパッキング（タンパク質分子の 規則的な配置）を見ると、いずれのタンパク質の場合にも、 安定な二量体形成を説明できるだけの面積をもつ接触面が存 在する（図2）。ところがCD38の場合には、29種類の結晶構 造が登録されたものの、その中に同様な接触面をもつパッキ ングは皆無であった。CD38の三次構造を見ると、アメフラ 
( $\alpha 9$ ) of human CD38 in the crystal is distinct from those of the other two members, and thus the $\alpha 9$ helices would clash if two CD38 molecules formed a dimer in the same manner as the Aplysia ADP-ribosyl cyclase and the soluble form of BST-1. Thus, CD38 may have a distinct homophilic interaction mode that enables tetramer formation on the cell surface. Interestingly, the existence of a tetrameric form of human CD38 has been demonstrated $(22,23)$.

\section{Structural Basis for CD38 Tetramerization}

The full-length extracellular domain of mouse CD38 exists as a homodimer in solution, as revealed by analytical ultracentrifugation and size exclusion chromatography analyses (24). In contrast, the homophilic interaction modes of CD38 were not suggested by the previous structural analysis of the full-length extracellular domain of human CD38, since the two molecules in the crystallographic unit lacked an apparent homodimer interface. However, our crystal structure of the C-terminal-truncated extracellular domain (accession code 2EG9) revealed types of interfaces (I-IV) in the crystal packing, as shown in Fig. 3B (the C-terminal truncation may have facilitated efficient crystal growth, by avoiding the amorphous aggregation through the weakening of the Type III interface) (24).

The interfaces (Types I-IV) suggested four types of homophilic interactions between CD38 monomers. The biochemical analysis revealed that the dimer of the extracellular domains of CD38, formed via the Type I interface, exists in equilibrium to form a tetramer via the Type II/III interfaces. The tetrameric interaction is compatible with membrane association (Fig. 4D).

To confirm that the interaction modes deduced from the crystal packing are actually involved in the CD38 assembly on the cell surface, a photo-reactive crosslinker, $p$-benzoyl-L-phenylalanine $(p \mathrm{Bpa})$, was separately introduced into CD38 at a defined position, using an expanded genetic code. After a position of interest is replaced with an amber codon, $p \mathrm{Bpa}$ can be introduced to the position by expressing a suppressor tRNA and the corresponding aminoacyl-tRNA synthetase. Using this method, the CD38 molecules became crosslinked when $p$ Bpa was separately introduced at the Type I and Type III interfaces (24). Accordingly, the combination of the Type I and Type II/III interfaces is considered to be the structural basis for the tetramerization of CD38 on the cell surface.

The Type I and Type II interfaces include several hydrophilic and hydrophobic interactions. Notably, the amino acid residues corresponding to the interactions are either conserved or semiconserved between mouse and human CD38.

CD38 has four potential N-glycosylation sites (N104/N124/ N213/N223). An analysis of the site-specific glycan of CD38 revealed that only the oligosaccharides attached to the N213 residue
シの ADPリボシルシクラーゼと CD157/BST-1 に比べてC末 端の $\alpha$-helix $(\alpha 9)$ の向きがほぼ90度回転しており、同様な二 量体構造をとると、 $\alpha 9$ 同士がぶつかってしまう。そこで夕 ンパク質のアセンブリにおいて、CD38はファミリーのほか の2種類のタンパク質とは異なる様式をもつことが予想され る。一方、生化学的な解析から CD38が四量体構造をとる例 が報告されていた $(22,23)$ 。

\section{CD38の四量体形成の構造基盤}

マウスCD38の細胞外ドメインは、超遠心やゲル濾過法 で解析すると見かけ上は二量体として挙動する $(24)$ 。すで に報告されたCD38の結晶中には、安定な二量体形成を説明 できるだけの面積をもつ接触面は見つかっていなかった。と ころが、C末端を欠失させたマウス CD38の細胞外ドメイン から得られた結晶における、タンパク質分子のパッキングに は、図3Bに示すような 4 種類の接触面が観察された（C末端 が関与する Type III 接触面の相互作用を弱めることにより不 規則な凝集が抑制され、結晶の成長に有利だったと考えられ る) $(24)$ 。

新たに得られた Type Iから Type IVまでの接触面の情報 をもとに、4種類のCD38の分子間相互作用が推定される。 生化学的な解析により、どの接触面が実際のタンパク質間相 互作用に寄与するかを検討したところ、水溶液中の CD38 細 胞外ドメインは、Type Iによる二量体と、これにさらに Type III と Type II の接触面が寄与して形成される四量体との平衡 状態にあることが結論された（図3C）。この四量体構造は、 膜貫通部分の位置から考えて、CD38が細胞膜上に存在する 場合にも成立する（図4D）。

構造解析の結果から推定されるタンパク質相互作用が細 胞表面でも起こっているかどうかを調べる方法として、人工 的なタンパク質合成系を用いた部位特異的な架橋反応が有 効である。すなわち架橋を導入したい部位がアンバーコド ンになるように遺伝子を改変し、サプレッサーtRNAとそれ に対応するアミノアシル合成酵素を共発現させることによ り、アンバーコドンに光クロスリンカーとなるアミノ酸 $(p-$ benzol-L-phenylalanine）を導入することができる。この方法 を用いて Type I, Type III の接触面に光架橋剤の導入を行った 場合に、細胞表面に発現しているマウスCD38が架橋された (24)。このことから細胞表面の CD38においても Type Iおよ びType II/III の接触面の組み合わせが四量体形成の構造基盤 であると考えられる。

マウス CD38の Type I, Type II の接触面では複数のイオン 結合と疎水性結合が形成される。これに関与するアミノ酸 は、ヒトCD38でも保存されているか、同様な性質をもつア ミノ酸が存在する。

マウスCD38には図1に示すようにN型糖鎖の推定付加 部位が 4 カ所存在する（N104/N124/N213/N223）。A20細胞に 

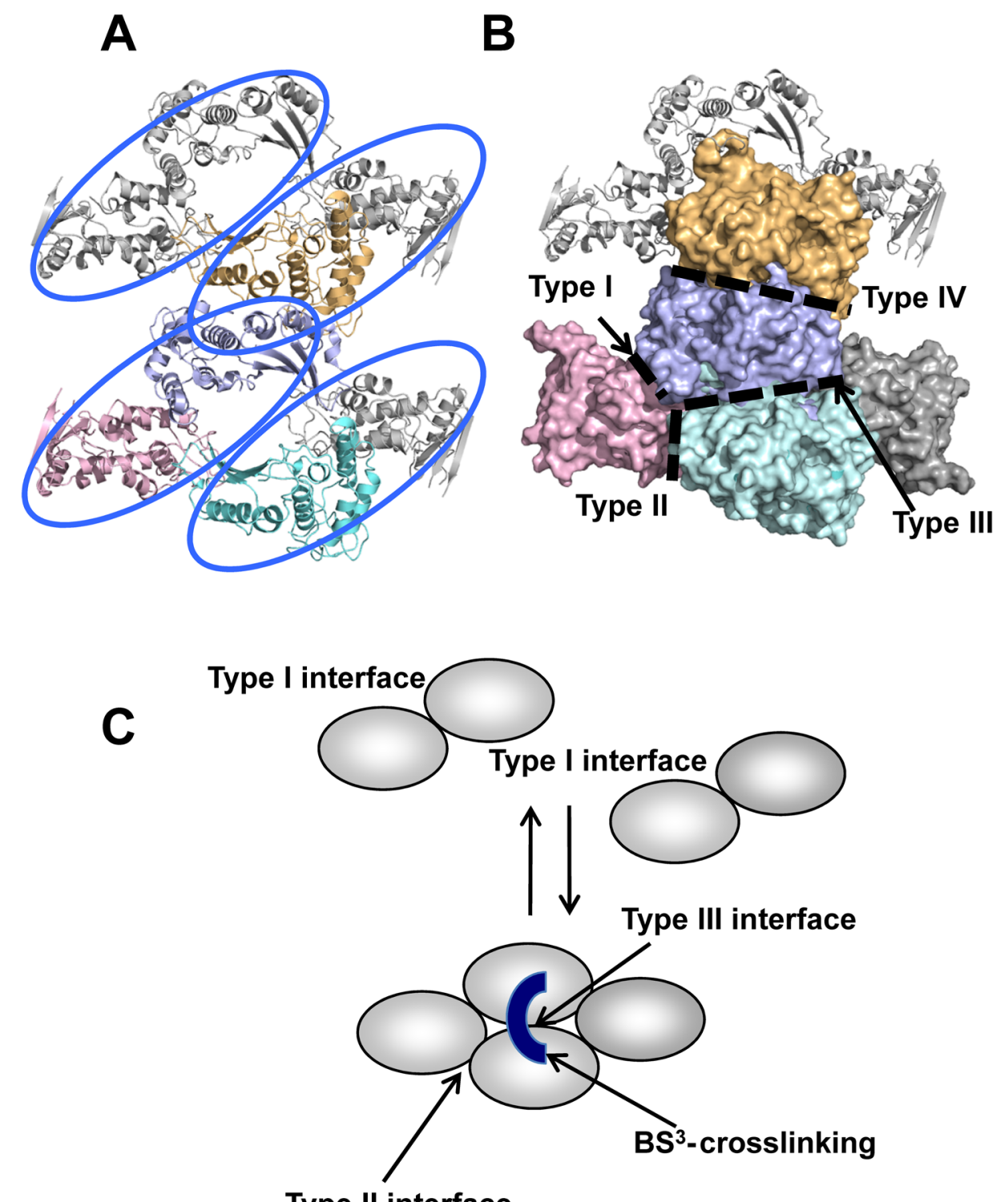

Type II interface

Fig. 3. The interfaces involved in the homophilic interactions of CD38. (A) The crystal packing of mouse CD38 (R48-F288) with asymmetric units (blue) (2EG9). (B) The four types of interfaces (I-IV). (C) The proposed dynamic equilibrium of the extracellular domain of CD38 in solution.

remained as the high-mannose-type, whereas the other three sites are occupied by mostly complex type oligosaccharides (24). Within the CD38 tetramer, the $\mathrm{N} 213$ residue faces the space between the extracellular domain and the membrane (Fig. 4E). This orientation would prevent the access of the processing enzymes. Accordingly, the high-mannose type oligosaccharides of the N213 residue are indicative of the tetramerization of CD38 during the N-glycan processing.

\section{The Tetrameric Interaction Is Crucial for the Catalytic Activity of CD38}

The extracellular domains of the ADP-ribosyl cyclase family
発現させたマウス CD38ではすべての部位に糖鎖が付加して いる。N104, N124, N223に結合している糖鎖は主に複合型 だったが、N213に結合している糖鎖だけは高マンノース型 であった (24)。細胞表面でCD38が四量体構造をとった場合 には、N213の糖鎖はタンパク質と膜とのすき間に向き、プ ロセシング酵素が接近しにくい位置に存在する（図4E）。 N213の糖鎖がプロセシング酵素による修飾を受けなかった ことは四量体を支持する結果である。

D. 四量体構造の形成はCD38の触媒活性に必要である ADP リボシルシクラーゼファミリーに属するタンパク 質の間で、触媒活性に重要な残基は保存されており、活性部 

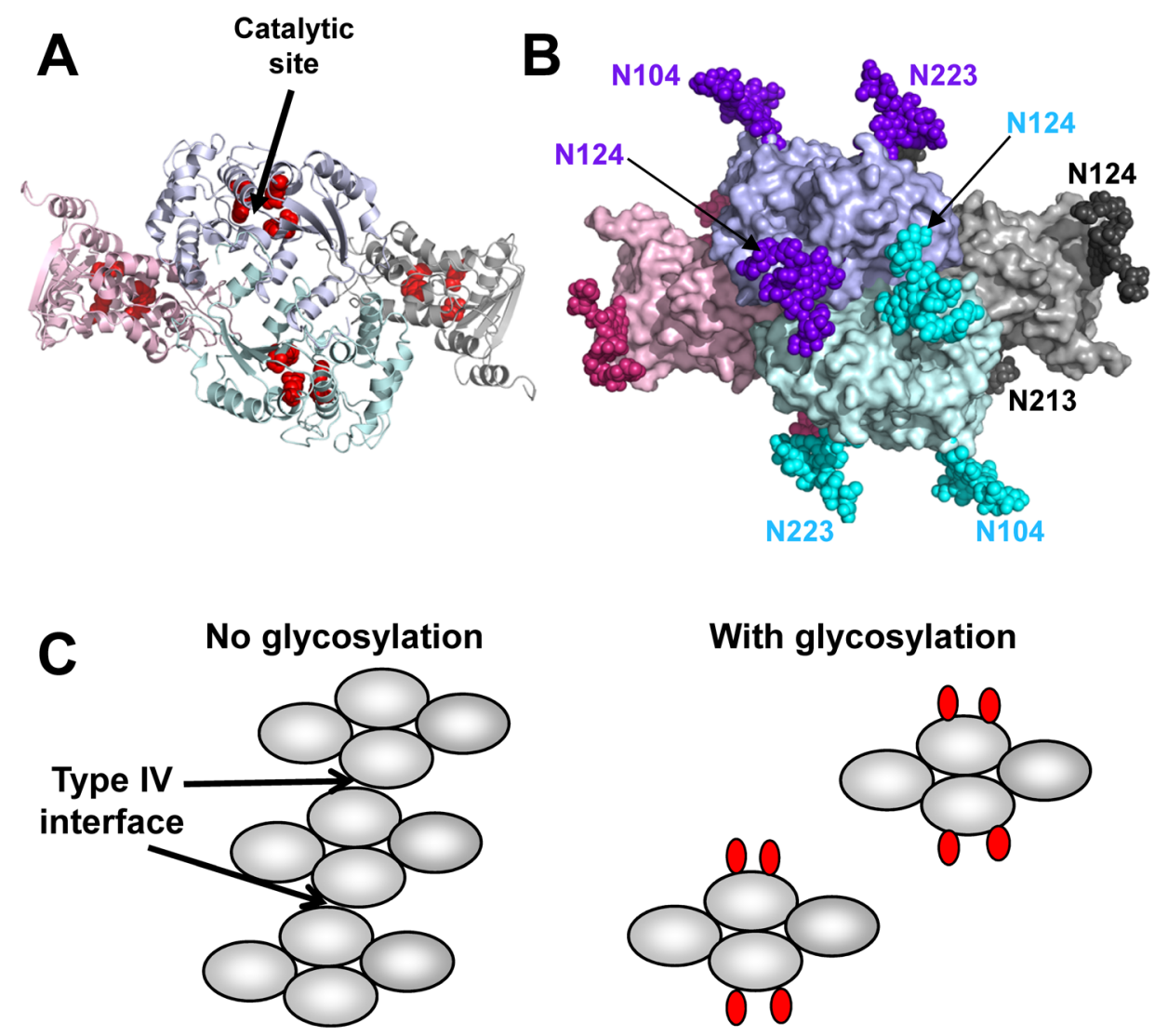

\section{With glycosylation}
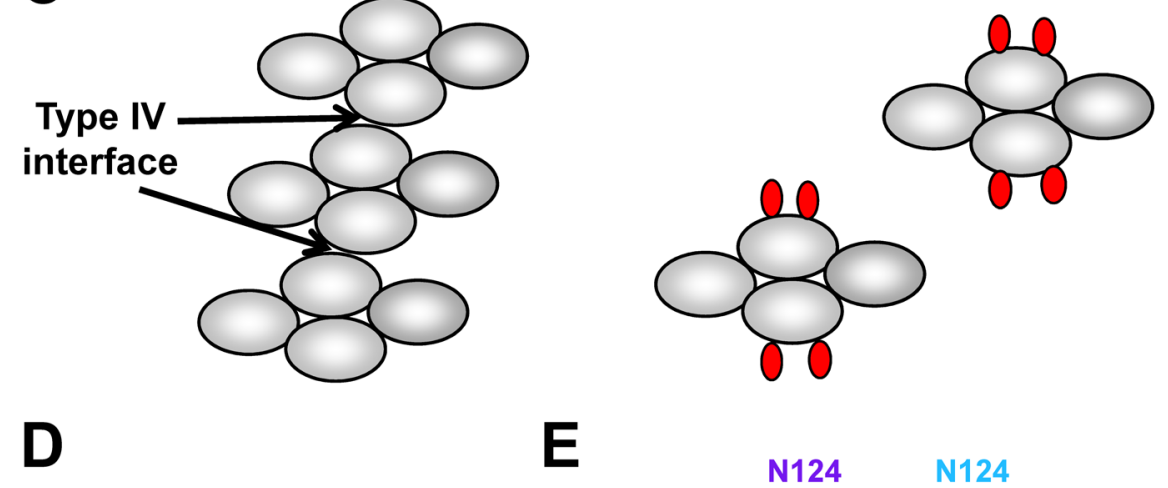

E $\quad$ N124 N124

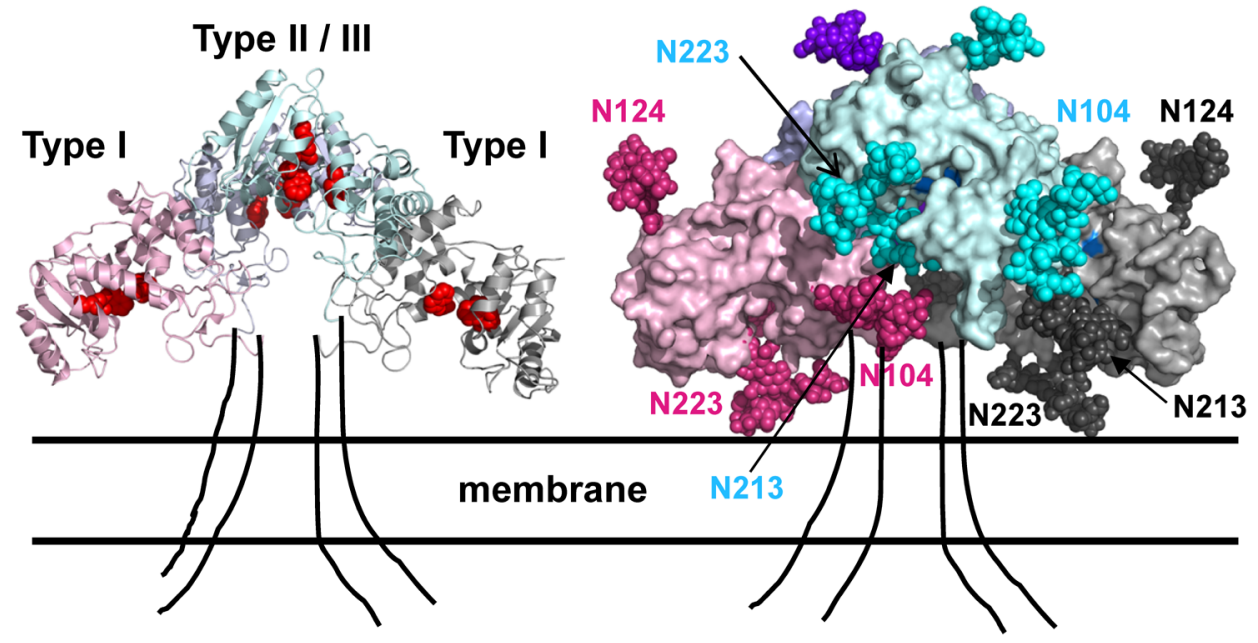

Fig. 4. Schematic representations of the dimer-of-dimer interactions of CD38 on the cell surface. The four molecules of human CD38 are assembled by the Type I and Type II/III interfaces, as in mouse CD38 (R48-F288) in the crystal (2EG9). The structures in D and E are shown in a perpendicular view to those in A and B, respectively. (A and D) The catalytically important residues are colored red. (B and E) The structure of the N-linked oligosaccharide moiety from a fat-depleting factor (1ZAG), composed of nine sugar residues, is attached to the residues corresponding to the N-glycosylation sites of mouse CD38 (N104/N124/N213/N223). (C) The role of glycosylation (shown in red) in suppressing the Type IV interface.

proteins are divided into the $\mathrm{N}$-domain and the C-domain. Among the family proteins, the catalytically important residues are located at spatially equivalent positions between these two domains, as
位は二つのドメインの間隙に存在する（図2)(17-19）。そこ で、活性部位が正しく形成されるためには、二つのドメイン の相対位置が一定に保たれることが必要である。 
shown in Fig. 2 (17-19). Accordingly, the proper orientation of the domains is crucial for catalytic-site formation.

The catalytic activities of both the isolated extracellular domain of CD38 and the cell-surface CD38 are appreciably decreased under conditions that suppress the tetrameric interaction (24). In addition, the $\mathrm{BS}^{3}$-crosslinking possibly occurs at the Type III interface, and the specific activity of the $\mathrm{NAD}^{+}$glycohydrolase was decreased at a lower concentration of the extracellular domain. These results suggested that the stabilization of the tetrameric interaction is required for the catalytic activity, by maintaining the proper arrangement of the two domains within each protomer (Fig. $4 \mathrm{~A})$.

\section{E. The Tetrameric Interaction Facilitates the Associa- tion of CD38 with Lipid Rafts}

Sphingolipids and cholesterol are the major components of mammalian cell membranes. The localization of proteins within cell membranes largely depends on these lipids. Some membrane proteins tend to associate with the regions enriched in sphingolipids and cholesterol (lipid rafts), where efficient protein-protein interactions occur (25). Lipid modifications, such as palmitoylation (26) or the GPI-anchor (27), are considered to promote the partitioning of the proteins into lipid rafts. On the other hand, the mechanism of transmembrane protein localization remains to be elucidated. There is no consensus that the specific amino acid sequences within the transmembrane region are responsible for the raft-localization.

CD38 is associated with lipid rafts. However, the amount of CD38 in lipid rafts is decreased when either the Type I or Type III interface is separately impaired, while the lipid species surrounding CD38 in lipid rafts are not affected (24). Thus, the tetrameric interaction may contribute to the association of CD38 with lipid rafts.

The clustering of membrane proteins enhances their targeting to membrane rafts. The clustering of TCR, BCR, and Fce RI, caused by antigen/MHC complexes or oligomeric antigens, facilitates their recruitment to membrane rafts, and triggers immune-recognition receptor signaling in $\mathrm{T}, \mathrm{B}$ and mast cells, respectively (28-30). The tetramerization of CD38 corresponds to an intrinsic clustering of CD38 on the cell surface, and thus can be interpreted as facilitating the association with lipid rafts. The underlying mechanism that enables the interaction of the bundle of four-transmembrane helices with the lipid rafts remains to be elucidated.
細胞外ドメイン細胞表面 CD38の場合にも、Type Iおよ びType IIIの接触面による相互作用が抑制されると触媒活性 が低下する $(24) 。 C D 38$ 細胞外ドメインの水溶液中での濃度

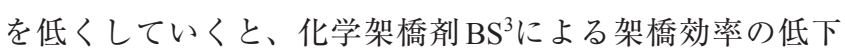
（Type IIIの接触面で起こると考えられる）に対応して比活性 の低下が見られる。これらの結果は、Type IおよびType III が共存して四量体構造が形成されることにより、それぞれ のCD38 分子内の二つのドメインの相対位置が一定に保持さ れてCD38の活性部位が形成されることを示唆している（図 $4 \mathrm{~A})$ 。

\section{E. 四量体構造の形成はCD38の脂質ラフトへの局在化に 重要である \\ 動物細胞の細胞膜には、主要な膜成分としてスフィンゴ} 脂質とコレステロールが含まれる。これらの脂質は細胞膜に おける膜タンパク質の局在化に影響を与える。ある種のタン パク質はスフィンゴ脂質とコレステロールに富む膜領域（脂 質ラフト）に存在しやすく、脂質ラフトにおいて効率的な夕 ンパク質間相互作用が起こる $(25)$ 。脂質ラフトに局在化しや すいタンパク質の特徴としては、脂質修飾（パルミチン酸の 付加、GPIアンカー) (26,27) が挙げられる。これに対して 膜貫通タンパク質が脂質ラフトに局在するしくみは明らかに なっていない。脂質ラフトへの局在化にかかわる特定のアミ ノ酸配列は報告されていない。

$\mathrm{CD} 38$ は脂質ラフトに局在する。マウス B 細胞由来 $\mathrm{A} 20$ 細胞にCD38を発現させた場合、四量体の形成が抑制される 条件では脂質ラフトへの局在が減少した $(24)$ 。CD38に結合 する脂質に変化は認められなかった。そこで、細胞外ドメイ ンが四量体構造を形成することがCD38の脂質ラフトへの局 在化に重要であると考えられる。

膜タンパク質を架橋すると脂質ラフトへの局在化が増加 する例は数多く知られている。代表的な例として、T細胞、 $\mathrm{B}$ 細胞、マスト細胞の免疫受容体のシグナルの開始におい て、抗原によって架橋された受容体が脂質ラフトに動員され る(28-30)。四量体構造の形成は、1 回膜貫通タンパク質が 架橋された状態に相当するために、現象論としては、脂質ラ フトへの局在化が増加したと解釈することができる。四量体 形成による CD38の 4 本の膜貫通 $\alpha$-ヘリックスの束が、膜脂 質の流動性が低い領域（脂質ラフト）と相互作用しやすい理 由を今後検討することが必要である。 


\section{F. Functional Aspects of N-Glycosylation in the Regu- lation of CD38 Assembly}

Although the association of glycosylated mouse CD38 with lipid rafts is somewhat hindered by the C-terminal truncation, the association of non-glycosylated mouse CD38 is not affected by the truncation (24). Thus, the glycosylated and non-glycosylated CD38 molecules associate with lipid rafts in different manners. The Nglycans attached to N104 and N223 preclude the formation of the Type IV interface (Fig. 4B). The N-glycans probably suppress further assembly of the CD38 tetramer on the cell surface, by inhibiting the formation of the "aggregating" Type IV interface (Fig. 4C).

The four potential N-glycosylation sites are also present in human CD38 (N100/N164/N209/N219). The sites corresponding to N104 and N223 in mouse CD38 are conserved (N100 and N219, respectively). Actually, in HeLa and MCF-7 cells, high molecular mass aggregates of $\mathrm{CD} 38$ were observed upon chemical crosslinking, in the absence of glycosylation (31).

In CD157/BST-1, a homologue of CD38, there is only one $\mathrm{N}$-glycosylation site, corresponding to N213 in mouse CD38. Therefore, the role of N-glycosylation of CD157/BST-1 is probably different from that of $\mathrm{CD} 38$.

\section{G. Interaction of CD38 with Daratumumab}

CD38 is highly expressed in hematological malignancies, including MMs (15) and chronic lymphocytic leukemia (3). In addition, anti-CD38 antibodies reportedly trigger cell survival or death, depending on the cell type. Actually, CD38 ligation induces the growth of murine splenic B cells (32) and leukemia cells from patients with acute myelogenous leukemia (33), and prevents the apoptosis of human tonsillar germinal center B cells (34). In contrast, CD38 ligation suppresses the growth of human bone marrow B cell progenitor cells (35), human immature B cell lines (36) and human myeloid cells from cord blood or normal bone marrow (37). In this context, $\mathrm{CD} 38$ is considered as a potential therapeutic $\mathrm{Ab}$ target for the treatment of MM.

Daratumumab, a human $\mathrm{mAb}$ against a unique CD38 epitope, induces potent $\mathrm{Ab}$-dependent cellular cytotoxicity in CD38expressing lymphoma- and MM-derived cell lines, as well as in cells from MM patients (15). Daratumumab stands out from the other CD38 mAbs, due to its strong ability to induce complementdependent cytotoxicity. These effects of daratumumab are observed even in the presence of bone marrow stromal cells, suggesting the effectiveness of daratumumab in a tumor-preserving bone marrow microenvironment. In vivo, daratumumab shows potent anti-tumor activity in mouse xenograft tumor models. A complementary effect is achieved by combining daratumumab and lenalidomide, a chemotherapeutic agent for MM treatment (38).

\section{F. CD38の糖鎖付加はタンパク質のアセンブリを制御す る}

糖鎖付加が起こらないマウス $\mathrm{CD} 38$ を $\mathrm{A} 20$ 細胞に発現さ せた場合には、糖鎖のある CD38 とは異なり、Type III 接触面 を弱める目的でC末端を欠失させても、脂質ラフトへの局在 は影響を受けなかった $(24)$ 。糖鎖がある場合とない場合で はCD38の脂質ラフトへの局在様式が異なっている。マウス CD38 の N104, N223 の糖鎖はType IV の接触を妨げる位置に 存在する (図 4B)。N型糖鎖はType IV の接触を抑制するこ とによりCD38の四量体がさらに会合することを抑制すると 考えられる(図4C)。

ヒト CD38の場合にも 4 力所の $\mathrm{N}$ 型糖鎖の推定付加部位 が存在する (N100/N164/N209/N219)。マウス CD38の N104, N223に相当する糖鎖付加部位はヒト CD38でも保存されてい る（N100 と N219）。HeLa細胞やMCF-7 細胞において、糖鎖 付加が起こらない状況では架橋剂によるCD38の凝集が見ら れることが報告されている(31)。

CD38のホモログである CD157/BST-1では、N型糖鎖の 推定付加部位は 1 力所のみであり、それはマウス CD38の N213に相当する。CD38 と CD157/BST-1では糖鎖の役割が異 なることが示唆される。

\section{G. CD38 とDaratumumab との相互作用}

CD38は白血病 (3) や多発性骨䯣腫（15）のような血液が んの細胞に高発現する。また抗 CD38抗体の刺激は細胞の種 類に応じて、細胞の増殖や細胞死を誘導する。マウス B 細胞 や急性骨髄性白血病患者からのB細胞では増殖を促進し(32, 33）、扁桃腺胚中心の B 細胞の細胞死を抑制する (34)。一方、 抗CD38抗体の刺激はヒト骨髄B細胞前駆細胞や、未分化ヒ 卜B細胞株、臍带血や骨髄のヒト骨髄細胞に対しては増殖を 抑制する(35-37)。こうした背景から CD38は抗体創薬の候 補と考えられた。

ヒトCD38に対するヒト型抗体Daratumumab は、CD38を 発現しているリンホーマや多発性骨髄腫由来細胞株、患者由 来の細胞に対して顕著な抗体依存性細胞傷害性を示す(15)。 またほかの抗ヒトCD38抗体とは異なり、補体依存性細胞傷 害性にも優れている。Daratumumabの細胞傷害性は骨髄ス卜 ローマ細胞共存下でも減弱しない。これは通常の抗がん剤に 対しては骨髄で生き延びるがん細胞にも、Daratumumabは殺 傷作用をもつことを示唆する。Daratumumabはマウスに移植 したがん細胞の増殖も抑制する。多発性骨髄腫の化学療法に 使われているレナリドミドとの併用により、Daratumumabの 抗腫瘍活性は顕著に増加する(38)。 


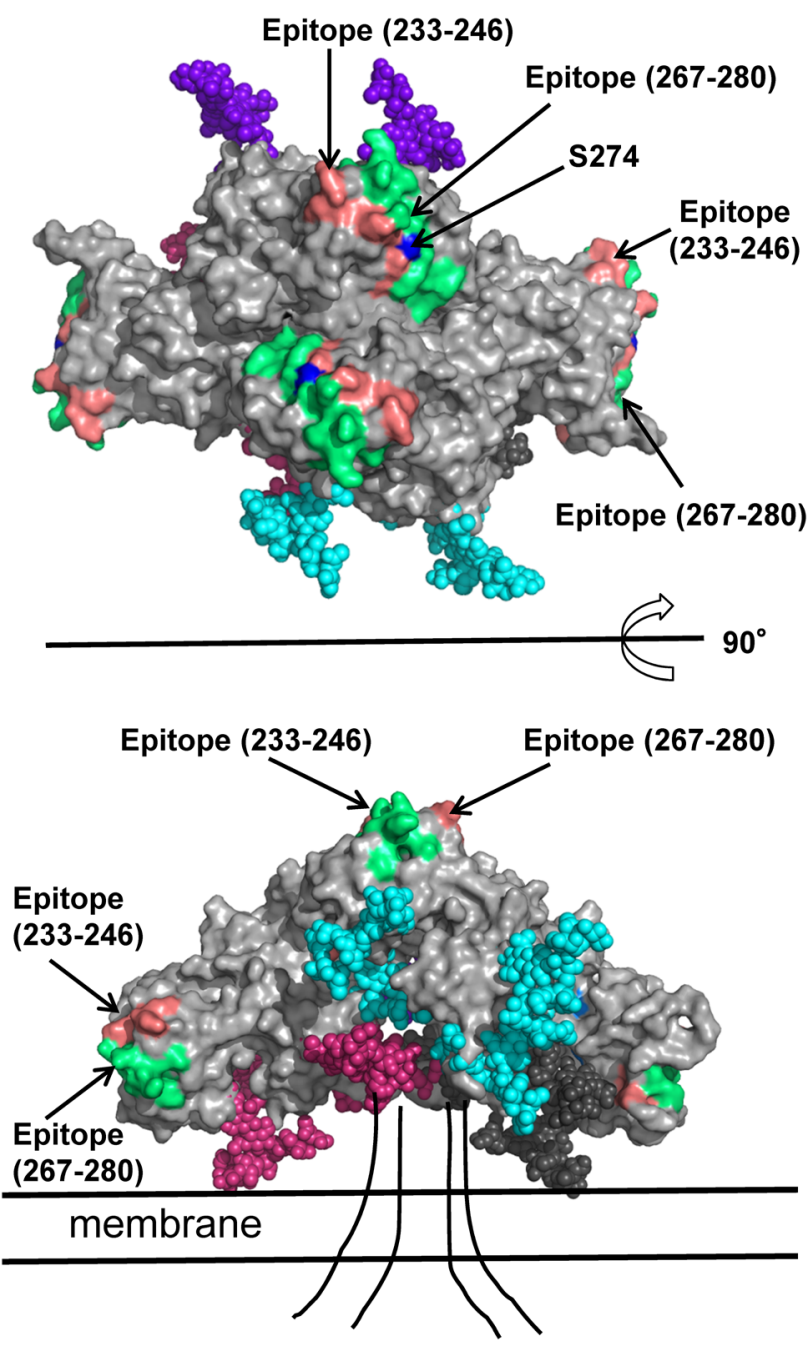

The epitope of daratumumab is present within two $\beta$-strands, containing amino acids 233-246 and 267-280 of CD38. The replacement of Ser274 with Phe (S274F) completely abolished daratumumab binding (15). If we consider the tetrameric assembly of human CD38 on the cell surface, the epitopes are located on the top and lateral sides (Fig. 5). The N-glycosylation probably does not interfere with the access of daratumuab, since the glycosylation site comparable to N124 in mouse CD38 is replaced with N164 in human CD38. It is conceivable that the binding of daratumumab affects the assembly of CD38 (either stabilization or destabilization).

\section{H. Concluding Remarks}

Based on results obtained with CD38-null mice, the enzymatic products of $\mathrm{CD} 38$ function inside the cells. Thus, there is the long-lasting topological problem of how the catalytic activity of the CD38 ectoenzyme is involved in intracellular calcium signaling. Although this problem has not been solved yet, two tentative
Fig. 5. Epitopes of daratumumab mapped on the tetrameric assembly of CD38 on the cell surface. The epitopes of daratumumab are shown in pink (233-246) and green (267-280) in two perpendicular views. The amino acid residue S274 is colored blue. The structures of the N-linked oligosaccharide moieties are attached to the residues corresponding to the $\mathrm{N}$-glycosylation sites of human CD38 (N100/N164/N209/N219).

Daratumumabのエピトープは233-246と267-280を含む 2 本の $\beta$-シートに存在する。またCD38の 274 番のセリンを フェニルアラニンに置換するとDaratumumabは結合しなく なる $(15)$ 。四量体構造をヒト CD38に適用すると、エピトー プは頂上と側面に存在する(図 5)。マウスCD38のN124に相 当する糖鎖付加部位はヒト CD38 ではN164であるため、N型 糖鎖はDaratumumabの接近には、おそらく影響を持たない。 Daratumumabが結合する位置はCD38の四量体構造のアセン ブリに影響を与える（安定化もしくは不安定化）可能性をも つ。

H. おわりに

CD38の触媒活性は細胞外ドメインに存在するにもかか わらず、ノックアウトマウスの実験結果によればCD38に よって産生される cADPR, NAADPが細胞内でのカルシウム 動員に関与する。この酵素活性と機能のトポロジーが食い 違うというジレンマは現在でも未解決の問題である。説明 
explanations have been proposed. Firstly, the products generated extracellularly are incorporated within the cytosol. Secondly, the topology of the extracellular domain of CD38 is reversed. In the former case, CD38 itself has been proposed to act as a channel for cADPR (39). As for the latter case, the occurrence of CD38 with an inverted topology, which has the extracellular domain facing toward the cytosol, has been reported recently (40). However, the mechanism of topological conversion remains unclear. Since the tetrameric assembly is vital for the catalytic activity, the assembly should be maintained, or at least re-formed, after the conversion. The tetrameric assembly is also important for the association of CD38 with lipid rafts, which can act as scaffolds for endocytosis (25). Further investigations of the relationships between the Nglycosylation-regulation, the tetrameric assembly of CD38, and the membrane dynamics will contribute toward solving the enigmatic topology of CD38.

In the course of protein crystallization for structural analysis, it is common to eliminate the glycosylation of the protein, to avoid heterogeneity. It is "mottainai" (an unfortunate loss) that, after the structural information is obtained, the knowledge about the functional aspects of glycosylation is still insufficient. Our results revealed that the glycosylation sites are located at strategic positions to preclude the aggregation of the CD38 tetramer on the cell surface. I would like to point out the usefulness of the structural data (now easily downloadable), which have provided new perspectives on glycosylation in the regulation of protein-protein interactions, in addition to cell-cell interactions.

\section{Acknowledgments}

The studies mentioned here were performed in collaboration with Dr. Mutsuko Niino, Dr. Motoaki Wakiyama, Dr. Kensaku Sakamoto, Dr. Mikako Shirouzu, Dr. Shigeyuki Yokoyama (RIKEN) and Dr. Nana Kawasaki (NIHS), together with many investigators, and were supported by Prof. Masaki Yanagishita (TMDU). The author thanks all of the contributors for their continuous support.
としては(1) 細胞外で産生された分子が細胞質に移動する、 （2）CD38の細胞外ドメインが細胞質に向く、という2 種類 の案がある。前者の場合にはCD38自身がcADPRのチャネ ルとして機能することが想定されている (39)。後者について は、通常のII型とは逆の配向をしたCD38が細胞膜に存在す ることが近年報告された $(40)$ 。しかし配向が逆転するメカ二 ズムは不明である。四量体構造は活性部位の維持に必須なの で、四量体のまま配置が逆転する（もしくは四量体が再形成 される）必要がある。四量体形成は脂質ラフトへの局在化に 重要であり、脂質ラフトはエンドサイトーシスの足場となる (25)。今後、糖鎖により制御される四量体形成と膜動態との 関連をさらに明らかにすることが、CD38のトポロジーに関 する問題を解明するための手掛かりになることが予想され る。

$\mathrm{X}$ 線結晶構造解析によりタンパク質の構造を決定する場 合、糖鎖の不均一性は結晶化に不向きであるという理由か ら、糖鎖を除去したサンプルが調製されることが一般的であ る。結晶構造の知見が糖鎖の機能にフィードバックされる例 が少ないのはもったいないことである。今回私たちはX線結 晶構造解析をもとにCD38の細胞表面でのアセンブリに着目 した研究を行い、糖鎖付加部位はCD38の四量体構造がさら に会合することを抑制する位置にあることを見いだした。糖 鎖の機能を考えるうえで、細胞間相互作用の制御に加えて、 $\mathrm{X}$ 線結晶構造解析の知見は（簡単にダウンロードできる）、 タンパク質間相互作用の制御という新たな視点を提供するこ とを指摘したい。

\section{謝 辞}

本稿で紹介した研究は、東京医科歯科大学において柳下 正樹先生のご支援のもとに、新野睦子先生、脇山素明先生、 坂本健作先生、白水美香子先生、横山茂之先生（理化学研究 所）、川崎ナナ先生（国立医薬品食品衛生研究所）、そして多 くの共同研究者の協力を得て行われました。深謝申し上げま す。

\section{References}

1. Jackson, D. G., and Bell, J. I. (1990) J. Immunol. 144, 2811-2815.

2. Cockayne, D. A., Muchamuel, T., Grimaldi, J. C., Muller-Steffner, H., Randall, T. D., Lund, F. E., Murray, R., Schuber, F., and Howard, M. C. (1998) Blood 92, 1324-1333.

3. Malavasi, F., Deaglio, S., Funaro, A., Ferrero, E., Horenstein, A. L., Ortolan, E., Vaisitti, T., and Aydin, S. (2008) Physiol. Rev. 88, 841-886.

4. Kato, I., Yamamoto, Y., Fujimura, M., Noguchi, N., Takasawa, S., and Okamoto, H. (1999) J. Biol. Chem. 274, $1869-1872$.

5. Takasawa, S., Nata, K., Yonekura, H., and Okamoto, H. (1993) Science 259, 370-373.

6. Jin, D., Liu, H. X., Hirai, H., Torashima, T., Nagai, T., Lopatina, O., Shnayder, N. A., Yamada, K., Noda, M., Seike, T., Fujita, K., Takasawa, S., Yokoyama, S., Koizumi, K., Shiraishi, Y., Tanaka, S., Hashii, M., Yoshihara, T., Higashida, K., Islam, M. S., Yamada, N., Hayashi, K., Noguchi, N., Kato, I., Okamoto, H., Matsushima, A., Salmina, A., Munesue, T., Shimizu, N., Mochida, S., Asano, M., and Higashida, H. (2007) Nature 446, $41-45$.

7. Partida-Sánchez, S., Cockayne, D. A., Monard, S., Jacobson, E. L., Oppenheimer, N., Garvy, B., Kusser, K., Goodrich, S., Howard, M., Harmsen, A., Randall, T. D., and Lund, F. E. (2001) Nat. Med. 7, 1209-1216. 
8. Partida-Sánchez, S., Goodrich, S., Kusser, K., Oppenheimer, N., Randall, T. D., and Lund, F. E. (2004) Immunity 20, $279-291$

9. Zubiaur, M., Izquierdo, M., Terhorst, C., Malavasi, F., and Sancho, J. (1997) J. Immunol. 159, 193-205.

10. Deaglio, S., Capobianco, A., Bergui, L., Dürig, J., Morabito, F., Dührsen, U., and Malavasi, F. (2003) Blood 102, $2146-2155$.

11. Deaglio, S., Vaisitti, T., Billington, R., Bergui, L., Omede', P., Genazzani, A. A., and Malavasi, F. (2007) Blood 109, $5390-5398$.

12. Deaglio, S., Zubiaur, M., Gregorini, A., Bottarel, F., Ausiello, C. M., Dianzani, U., Sancho, J., and Malavasi, F. (2002) Blood 99, $2490-2498$.

13. Zilber, M. T., Setterblad, N., Vasselon, T., Doliger, C., Charron, D., Mooney, N., and Gelin, C. (2005) Blood 106, 3074-3081.

14. Frasca, L., Fedele, G., Deaglio, S., Capuano, C., Palazzo, R., Vaisitti, T., Malavasi, F., and Ausiello, C. M. (2006) Blood 107, $2392-2399$.

15. de Weers, M., Tai, Y. T., van der Veer, M. S., Bakker, J. M., Vink, T., Jacobs, D. C., Oomen, L. A., Peipp, M., Valerius, T., Slootstra, J. W., Mutis, T., Bleeker, W. K., Anderson, K. C., Lokhorst, H. M., van de Winkel, J. G., and Parren, P. W. (2011) J. Immunol. 186, $1840-1848$.

16. Quarona, V., Zaccarello, G., Chillemi, A., Brunetti, E., Singh, V. K., Ferrero, E., Funaro, A., Horenstein, A. L., and Malavasi, F. (2013) Cytometry B Clin. Cytom. 84, 207-217.

17. Prasad, G. S., McRee, D. E., Stura, E. A., Levitt, D. G., Lee, H. C., and Stout, C. D. (1996) Nat. Struct. Biol. 3, 957-964.

18. Yamamoto-Katayama, S., Ariyoshi, M., Ishihara, K., Hirano, T., Jingami, H., and Morikawa, K. (2002) J. Mol. Biol. 316, 711-723.

19. Liu, Q., Kriksunov, I. A., Graeff, R., Munshi, C., Lee, H. C., and Hao, Q. (2005) Structure (London, England: 1993) 13, $1331-1339$.

20. Munshi, C., Baumann, C., Levitt, D., Bloomfield, V. A., and Lee, H. C. (1998) Biochim. Biophys. Acta 1388, 428-436.

21. Sato, A., Yamamoto, S., Kajimura, N., Oda, M., Usukura, J., and Jingami, H. (1999) Eur. J. Biochem. 264, 439-445.

22. Bruzzone, S., Guida, L., Franco, L., Zocchi, E., Corte, G., and De Flora, A. (1998) FEBS Lett. 433, 275-278.

23. Franco, L., Zocchi, E., Calder, L., Guida, L., Benatti, U., and De Flora, A. (1994) Biochem. Biophys. Res. Commun. $202,1710-1715$.

24. Hara-Yokoyama, M., Kukimoto-Niino, M., Terasawa, K., Harumiya, S., Podyma-Inoue, K. A., Hino, N., Sakamoto, K., Itoh, S., Hashii, N., Hiruta, Y., Kawasaki, N., Mishima-Tsumagari, C., Kaitsu, Y., Matsumoto, T., Wakiyama, M., Shirouzu, M., Kasama, T., Takayanagi, H., UtsunomiyaTate, N., Takatsu, K., Katada, T., Hirabayashi, Y., Yokoyama, S., and Yanagishita, M. (2012) Structure 20, 1585-1595.

25. Simons, K., and Sampaio, J. L. (2011) Cold Spring Harb. Perspect. Biol. 3, a004697.

26. Zhang, W., Trible, R. P., and Samelson, L. E. (1998) Immunity 9, 239-246.

27. Rodgers, W., Crise, B., and Rose, J. K. (1994) Mol. Cell. Biol. 14, 5384-5391.

28. Jury, E. C., Flores-Borja, F., and Kabouridis, P. S. (2007) Semin. Cell Dev. Biol. 18, 608-615.

29. Gupta, N., and DeFranco, A. L. (2007) Semin. Cell Dev. Biol. 18, 616-626.

30. Silveira, E. S. A. M., Mazucato, V. M., Jamur, M. C., and Oliver, C. (2011) J. Lipids 2011, 752906.

31. Gao, Y., and Mehta, K. (2007) Mol. Cell. Biochem. 295, 1-7.

32. Santos-Argumedo, L., Teixeira, C., Preece, G., Kirkham, P. A., and Parkhouse, R. M. (1993) J. Immunol. 151, 3119-3130.

33. Konopleva, M., Estrov, Z., Zhao, S., Andreeff, M., and Mehta, K. (1998) J. Immunol. 161, 4702-4708.

34. Zupo, S., Rugari, E., Dono, M., Taborelli, G., Malavasi, F., and Ferrarini, M. (1994) Eur. J. Immunol. 24, $1218-1222$.

35. Kumagai, M., Coustan-Smith, E., Murray, D. J., Silvennoinen, O., Murti, K. G., Evans, W. E., Malavasi, F., and Campana, D. (1995) J. Exp. Med. 181, 1101-1110.

36. Kitanaka, A., Ito, C., Nishigaki, H., and Campana, D. (1996) Blood 88, 590-598.

37. Todisco, E., Suzuki, T., Srivannaboon, K., Coustan-Smith, E., Raimondi, S. C., Behm, F. G., Kitanaka, A., and Campana, D. (2000) Blood 95, $535-542$.

38. van der Veer, M. S., de Weers, M., van Kessel, B., Bakker, J. M., Wittebol, S., Parren, P. W., Lokhorst, H. M., and Mutis, T. (2011) Haematologica 96, 284-290.

39. Franco, L., Guida, L., Bruzzone, S., Zocchi, E., Usai, C., and De Flora, A. (1998) FASEB J. 12, 1507-1520.

40. Zhao, Y. J., Lam, C. M., and Lee, H. C. (2012) Sci. Signal. 5, ra67.

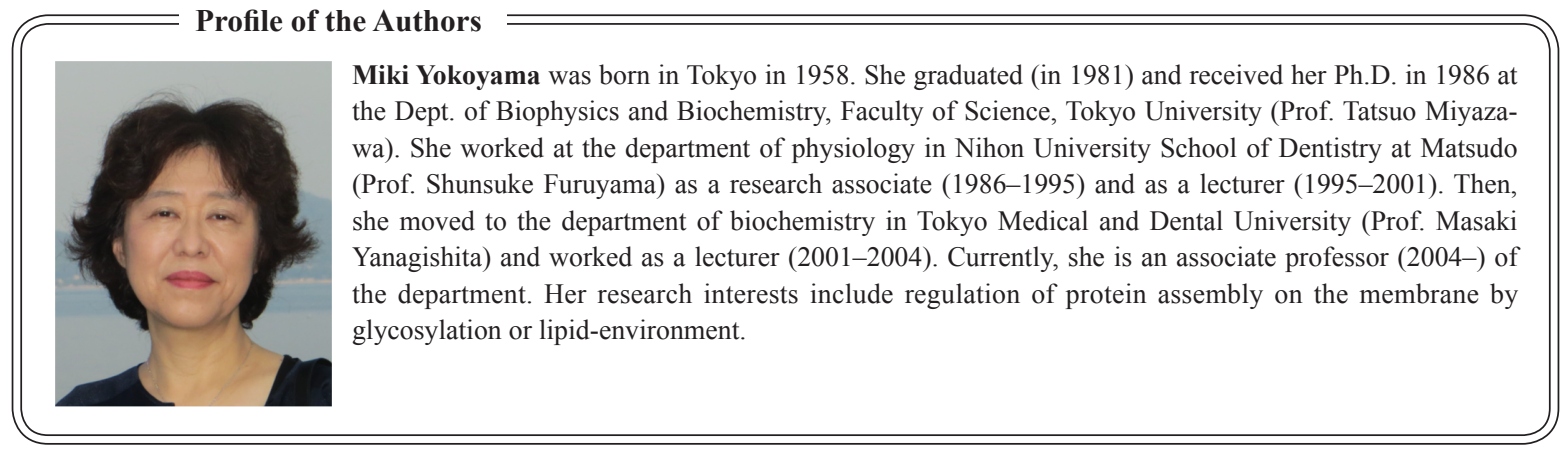

